\title{
Upper and lower mesophotic coral reef fish communities evaluated by underwater visual censuses in two Caribbean locations
}

\author{
H. T. Pinheiro ${ }^{1,2}$ - G. Goodbody-Gringley ${ }^{3}$ M. E. Jessup ${ }^{1} \cdot$ B. Shepherd ${ }^{1}$ • \\ A. D. Chequer ${ }^{4}$ L. A. Rocha ${ }^{1,2}$
}

Received: 1 February 2015/ Accepted: 20 November 2015/Published online: 24 December 2015

(C) The Author(s) 2015. This article is published with open access at Springerlink.com

\begin{abstract}
Despite more than $60 \mathrm{yr}$ of coral reef research using scuba diving, mesophotic coral ecosystems (MCEs) between 30 and $150 \mathrm{~m}$ depth remain largely unknown. This study represents the first underwater visual census of reef fish communities in the Greater Caribbean on MCEs at depths up to $80 \mathrm{~m}$ in Bermuda and $130 \mathrm{~m}$ in Curaçao. Sampling was performed using mixed-gas closed-circuit rebreathers. Quantitative data on reef fish communities were obtained for four habitats: coral reefs $(45-80 \mathrm{~m})$, rhodolith beds $(45-80 \mathrm{~m})$, ledges $(85-130 \mathrm{~m})$ and walls $(85-130 \mathrm{~m})$. A total of 38 species were recorded in Bermuda and 66 in Curaçao. Mesophotic reef fish communities varied significantly between the two localities. MCEs in Bermuda had lower richness and abundance, but higher biomass than those in Curaçao. Richness, abundance and biomass increased with depth in Bermuda, but decreased in Curaçao. A high turnover of species was found among depth strata and between Bermuda and other Caribbean
\end{abstract}

Communicated by Biology Editor Dr. Andrew Hoey

Electronic supplementary material The online version of this article (doi:10.1007/s00338-015-1381-0) contains supplementary material, which is available to authorized users.

H. T. Pinheiro

htpinheiro@gmail.com

1 California Academy of Sciences, 55 Music Concourse Drive, Golden Gate Park, San Francisco, CA 94118, USA

2 Department of Ecology and Evolutionary Biology, University of California Santa Cruz, 100 Shaffer Road, Santa Cruz, CA 95060, USA

3 Bermuda Institute of Ocean Sciences, 17 Biological Lane, St. George's GE01, Bermuda

4 Ocean Support Foundation, Suite 1222, 48 Par la Ville Road, Hamilton HM11, Bermuda upper MCEs (45-80 m), indicating that depth was an important driver of community structure at all localities. However, local and evolutionary factors (habitat and endemism) are likely the main factors shaping communities in isolated locations such as Bermuda. High fishing pressure is evident in both localities, as total biomass of apex predators was generally low, and thus may be driving a "refugia" scenario in Bermuda, as the abundance and biomass of macro-carnivores increased with depth and distance from the coast.

Keywords Bermuda $\cdot$ Biodiversity $\cdot$ Biogeography · Curaçao $\cdot$ Deep reefs $\cdot$ Ecology

\section{Introduction}

Despite more than $60 \mathrm{yr}$ of coral reef research using scuba diving across the Greater Caribbean (Hixon 2011), mesophotic coral ecosystems (MCEs) between 30 and $150 \mathrm{~m}$ depth remain largely unknown (Bak et al. 2005; Kahng et al. 2010). Most characterizations of MCE fish assemblages use submersibles or remotely operated vehicles (Colin 1974, 1976; Bryan et al. 2013), while reef fish community structure analyses using conventional scuba are sparse and operationally (depth and time) limited (Lukens 1981; Feitoza et al. 2005). Recent advances in mixed-gas closed-circuit rebreather technology (which has much higher autonomy underwater and is bubble-free), however, now allow more comprehensive characterizations of MCEs (Garcia-Sais 2010; Lesser and Slattery 2011; Bejarano et al. 2014).

The initial studies focusing on MCEs highlighted ecological changes with depth, such as shifts in abundance, species richness and community structure (Lukens 1981; 
Dennis and Bright 1988; Liddell and Ohlhorst 1988). These studies documented a decrease in the abundance of herbivorous and omnivorous fishes with depth, along with an increase in abundance of planktivores and carnivores (Thresher and Colin 1986; Bejarano et al. 2014). The discovery of high biodiversity in MCEs has led many researchers to propose that deep reefs may serve as refugia for shallow-water species (Feitoza et al. 2005; Bejarano et al. 2014). The "deep reef refugia" hypothesis posits that mesophotic zones may be protected from biotic and abiotic impacts that typically occur on shallow-water coral reefs and thus may serve as a source for future repopulation of shallow regions (Bongaerts et al. 2010). Yet the majority of studies undertaken to date only examine mesophotic zones shallower than $80 \mathrm{~m}$, with limited information available on ecological changes or refuge function in deeper mesophotic regions $(85-150 \mathrm{~m})$.

Recent biodiversity assessments using submersibles and technical diving have documented the presence of previously unidentified species in lower mesophotic zones (e.g., Sparks and Gruber 2012; Baldwin and Robertson 2013; Baldwin and Johnson 2014), illustrating that our understanding of fish communities and biodiversity at these depths is minimal. This study, therefore, aimed to expand the knowledge of Caribbean MCEs through comparisons of mesophotic reef fish communities in Bermuda and Curaçao by means of underwater visual censuses (UVC). Results from these surveys show differences in density, biomass and richness of reef fish communities between these two locations and between upper and lower mesophotic reefs for the first time and provide insights into biogeographic and ecological patterns and processes on Caribbean MCEs.

\section{Methods}

\section{Study area}

This study was conducted at two oceanic islands, Bermuda $\left(32^{\circ} 18^{\prime} \mathrm{N}, 64^{\circ} 46^{\prime} \mathrm{W}\right)$, the northernmost island of the Caribbean Province, and Curaçao $\left(12^{\circ} 05^{\prime} \mathrm{N}, 68^{\circ} 53^{\prime} \mathrm{W}\right)$, in the southern Caribbean (Fig. 1). A recent analysis of the composition of reef fish communities places these locations in different biogeographic provinces (Robertson and Cramer 2014). Bermuda is a volcanic island located $1049 \mathrm{~km}$ (652 nm) southeast of Cape Hatteras, US central east coast, and represents the northernmost coral reef system in the Atlantic. Reefs persist in Bermuda partly due to the flow of the Gulf Stream, bringing warm water from the Gulf of Mexico (Coates et al. 2013; Locke et al. 2013a). Annual sea surface temperatures range from 15 to $30{ }^{\circ} \mathrm{C}$, which allows a variety of tropical marine organisms to live in this region, including 38 scleractinian coral species (Locke et al. 2013b). The top of the seamount upon which Bermuda lies has a total reef area of $177 \mathrm{~km}^{2}$. Shallow-water coral cover in Bermuda ranks among the highest in the Caribbean with an estimated mean overall cover of $38.6 \%$ (Jackson et al. 2014). Deep reef zones (below 50-60 m), however, are composed of extensive rhodolith beds and sparse scleractinian corals (Smith-Vaniz et al. 1999).

Curaçao is an oceanic island situated $60 \mathrm{~km}$ north of Venezuela. It is the largest island of the Dutch West Indies at $61 \mathrm{~km}$ long and $14 \mathrm{~km}$ wide. Sea surface temperature varies between 26 and $29^{\circ} \mathrm{C}$. The island is surrounded by a fringing reef $20-250 \mathrm{~m}$ from the coast and covering a total surface of $7.85 \mathrm{~km}^{2}$. Sixty-five coral species are found in Curaçao, with estimated mean coral cover ranging from $13.3 \%$ on the northwest side of the island to $31.5 \%$ on the southwest (Jackson et al. 2014) and peak coral cover reaching up to $70 \%$ in some shallow regions (Vermeij 2012).

\section{Data sampling}

Five sites ranging 50-80 $\mathrm{m}$ depth were sampled in July 2014 on the south shore of Bermuda, and six sites between 45 and $130 \mathrm{~m}$ depth were sampled in December 2014 on the southwestern coast of Curaçao, next to the Curaçao Sea Aquarium. Habitats consisted of coral reefs and rhodolith beds (mostly agglutinated) in the shelf of Bermuda (Fig. 2a-d), and coral reefs $(45-80 \mathrm{~m})$, ledges and walls (85-130 m) in Curaçao (Fig. 2e-h). In general, all sampled sites and habitats of Curaçao displayed a steeper slope than Bermuda. However, most transects were run in high and medium complexity habitats at both locations. The sites were visited by our team or research partners prior to sampling, and transect areas were selected to cover the diversity of habitats of each area. Divers used closed-circuit mixed-gas rebreathers (Hollis Prism2).

Although a similar number of dives were conducted in each location, differences in technical diving logistics required different sampling effort and strategies. In Bermuda, every dive was performed in a specific habitat and depth stratum, and decompression occurred in open water (this limited the total bottom time of the dive). In contrast, in Curaçao, dives covered different habitat and depth strata, and decompression occurred along the reef slope. Thus, two to six 30-m transects were obtained per site, totaling 14 visual censuses in Bermuda (three at $45-50 \mathrm{~m}$; nine at 60-65 m; two at $70-80 \mathrm{~m}$ ) and 22 in Curaçao (five at $45-50 \mathrm{~m}$; four at $60-65 \mathrm{~m}$; four at $70-80 \mathrm{~m}$; four at $85-90 \mathrm{~m}$; five at $105-130 \mathrm{~m}$ ). All species were counted within $1 \mathrm{~m}$ of each side of the transect tape for a total area of $60 \mathrm{~m}^{2}$ per survey (e.g., Lesser and Slattery 2011; Pinheiro et al. 2011, 2013). Abundance and body size $(5 \mathrm{~cm}$ 
Fig. 1 The Greater Caribbean showing geographic position of surveyed islands Bermuda and Curaçao, as well as Puerto Rico, where previously published data were available

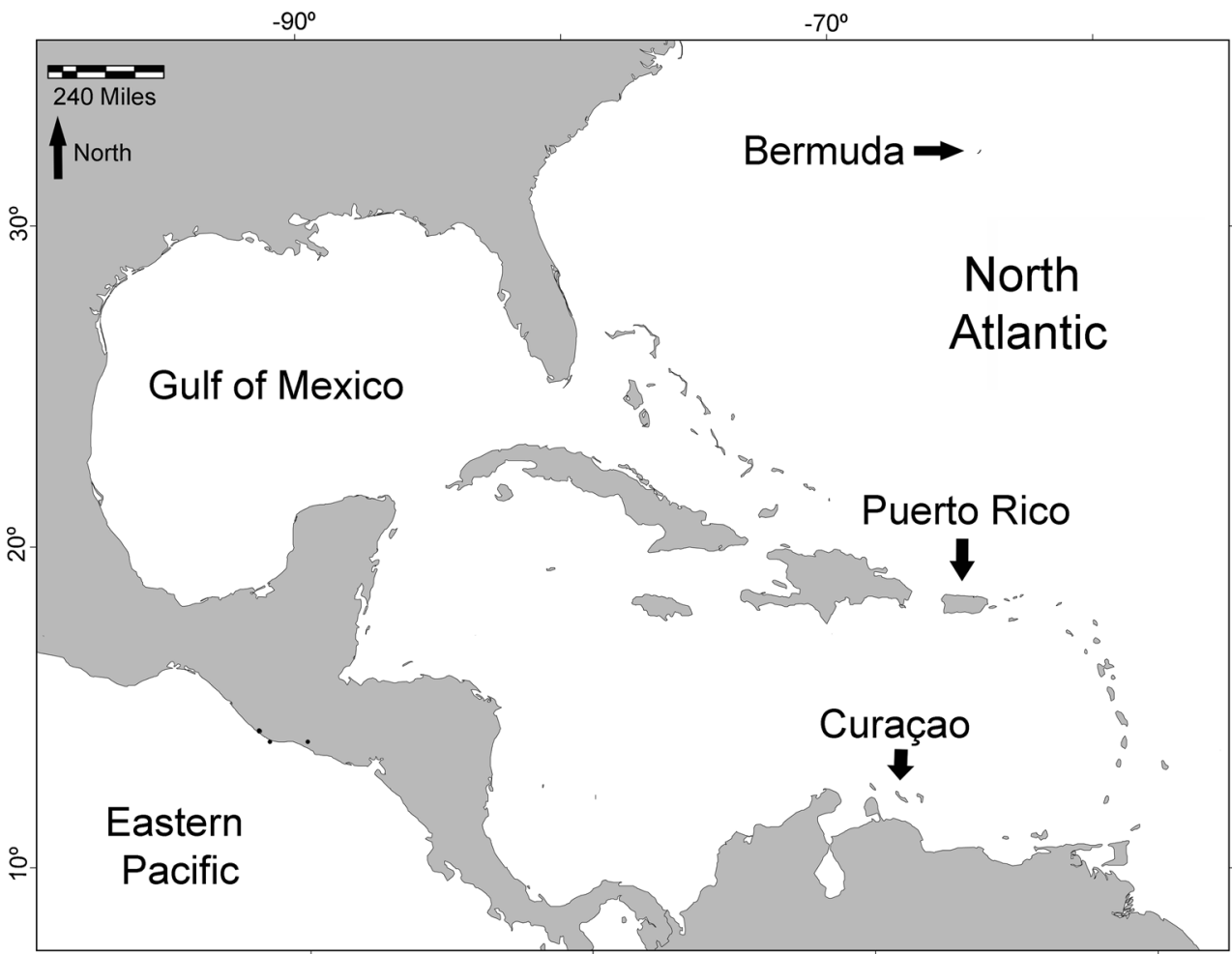

size classes) were estimated for each species observed along the transects.

\section{Data analysis}

"Upper" and "lower" mesophotic zone classifications, 45-85 and 85-130 m, respectively, were determined based on observation of light availability and corroborated by fish fauna turnover. Light decreases dramatically below the ledge $(\sim 85 \mathrm{~m})$ along the wall, and a flashlight is necessary to visually assess fish assemblages.

Trophic guilds were classified following Ferreira et al. (2004) and Pinheiro et al. (2011) and comprised macrocarnivores, territorial herbivores, roving herbivores, mobile invertebrate feeders, sessile invertebrate feeders, omnivores and planktivores. Fish biomass was estimated using length-weight relationships from Froese and Pauly (2014). When no equation was available for a given species, average estimates for the genus or family were used (Froese and Pauly 2014).

A multidimensional scaling (MDS) analysis was performed to explore the variation in fish composition and abundance between the upper mesophotic zone of each locality and among depth strata. Fish biomass, density and richness were compared between the upper mesophotic zone of each locality using a Mann-Whitney $U$ test (Zar 2010). Kruskal-Wallis $H$ tests were used to compare fish biomass, density and richness among depth strata (Zar
2010). Analyses of similarities (ANOSIM) were used to evaluate possible differences in the structure of fish communities between localities and depth strata. A matrix of average fish abundance by depth strata was built and a cluster analysis conducted using Bray-Curtis similarity and UPGMA joining method. In order to disentangle the role of depth and geographic distance as drivers of community structure, data from upper mesophotic zones of Puerto Rico (50-70 m, modified to counts per $60 \mathrm{~m}^{2}$ from Bejarano et al. 2014) were added to the matrix. SIMPER analyses were conducted to assess species contribution to withincluster Bray-Curtis similarity and to inter-group BrayCurtis dissimilarities. The MDS, ANOSIM, Cluster and SIMPER analyses were performed using PRIMER, and the Mann-Whitney and Kruskal-Wallis tests were run using SPSS 16.

\section{Results}

\section{Mesophotic reef fish communities}

A total of 38 species were recorded in the mesophotic reefs of Bermuda and 66 in Curaçao (Electronic Supplementary Material, ESM Table S1). Upper mesophotic reef fish communities in Bermuda and Curaçao differed significantly (Fig. 3a; ANOSIM Global $R=0.491 ; P=0.001$ ). Bermuda had lower species richness ( $U$ test, $Z=-3.842$, 

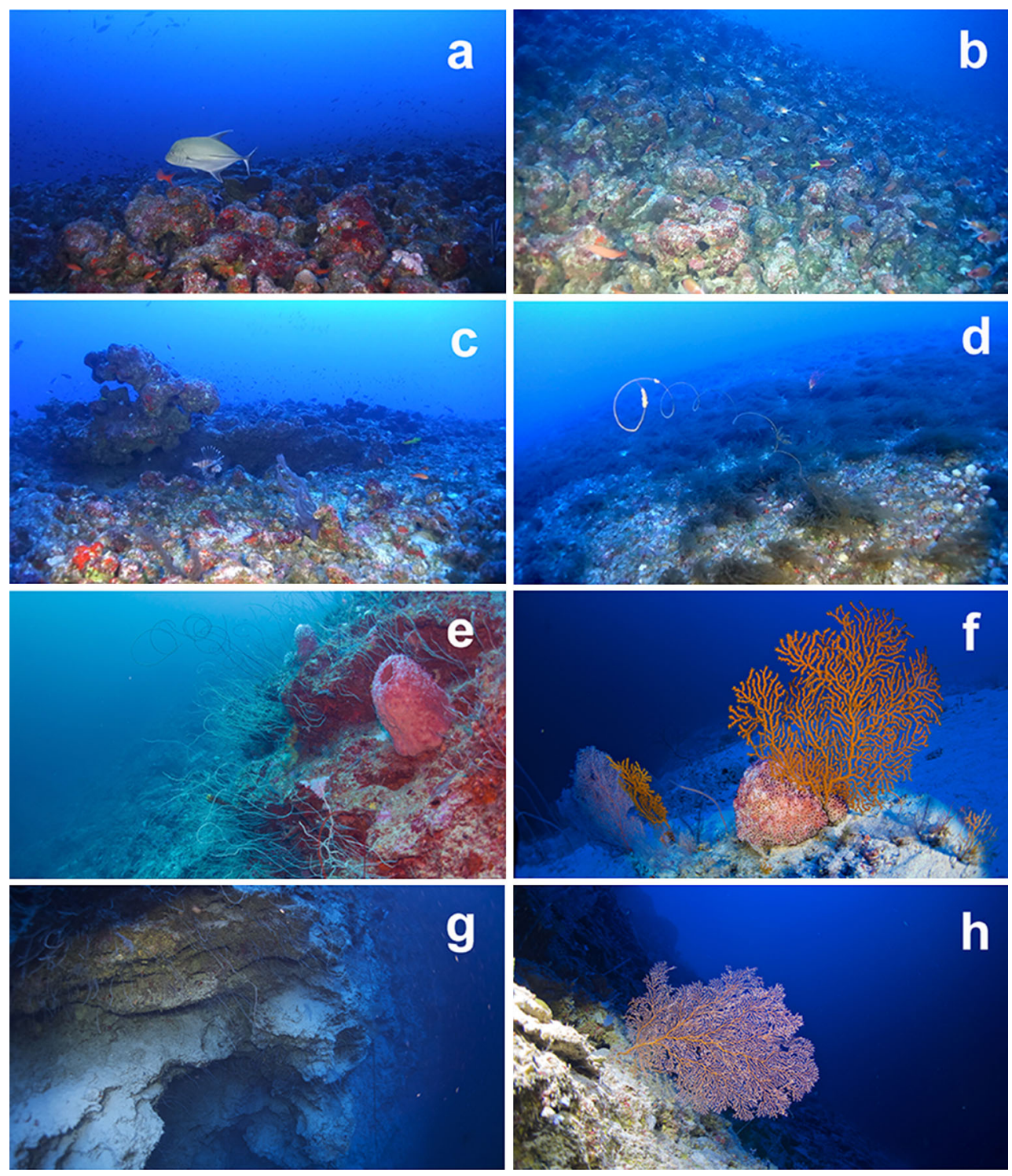

Fig. 2 Mesophotic reef environments assessed in Bermuda: a top of biogenic reef, $\mathbf{b}$ reef slope, $\mathbf{c}$ interface between reef structure and rhodolith bed, d extensive rhodolith bed; and Curaçao: e upper mesophotic coral reef, $\mathbf{f}$ mesophotic patch of sand, $\mathbf{g}$ carbonate reef wall and $\mathbf{h}$ lower mesophotic reef slope
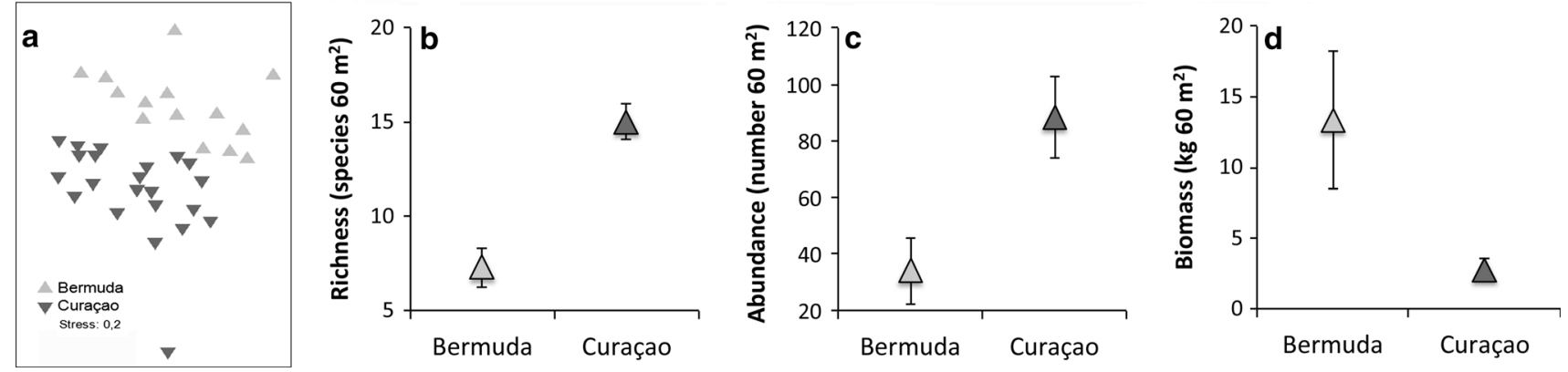

Fig. 3 MDS analysis of Bray-Curtis similarity of reef fish abundance (number $60 \mathrm{~m}^{-2}$ ) (a); mean values ( \pm SE) of richness $(\mathbf{b})$, abundance (c) and biomass (d) of mesophotic reef fish communities of Bermuda (light gray triangles) and Curaçao (dark gray triangles), Western Atlantic 
$P<0.001$ ) and fish abundance ( $U$ test, $Z=-2.961$, $P=0.002$ ), but higher biomass (although not significant; $U$ test, $Z=-1.165, P=0.259$ ) than Curaçao (Fig. 3b-d). The most abundant trophic guilds in Bermuda were planktivores (Paranthias furcifer and Chromis aff. enchrysura), roving herbivores (Kyphosus spp. and Scarinae spp.), macro-carnivores (Carangidae and Pterois volitans) and mobile invertebrate feeders (Holocentridae and Labridae) (Fig. 4a). In Curaçao, the most abundant trophic group was mobile invertebrate feeders (high numbers of Coryphopterus spp. and Antilligobius nikkiae), followed by planktivores (Chromis spp.) and territorial herbivores (Stegastes partitus) (Fig. 4b).

The trophic guild with highest biomass in Bermuda was roving herbivores (Kyphosus sp.), followed by macro-carnivores (Carangidae, P. volitans and Epinephelidae), mobile invertebrate feeders (Holocentridae) and sessile invertebrate feeders (Holacanthus tricolor and Chaetodon sedentarius) (Fig. 4c). The groups with highest biomass in Curaçao were macro-carnivores (Lutjanidae, Epinephelidae and $P$. volitans) and mobile invertebrate feeders (Haemulon spp. and Holocentridae) (Fig. 4d).

\section{Depth gradients}

In general, of the 89 species recorded in this study, 63 $(71 \%)$ were found exclusively in the upper mesophotic zone $(45-80 \mathrm{~m})$, seven $(8 \%)$ were exclusively from the lower mesophotic zone $(85-130 \mathrm{~m})$, and $19(21 \%)$ were found in both zones (ESM Table S1).

Community structure in both localities changed with depth stratum (Figs. 5, 6, 7; ANOSIM Bermuda, Global $R=0.239, \quad P=0.043 ; \quad$ ANOSIM Curaçao, Global $R=0.448, P=0.002$ ). Changes in species richness, fish abundance and biomass occurred in opposite directions in the two localities (Fig. 5b-d, f-h). In Bermuda, all community parameters increased with depth (Fig. 5b-d; richness $H$ test, $X^{2}=6.342, P=0.042$; abundance $H$ test, $X^{2}=8.177, \quad P=0.017$; biomass $H$ test, $X^{2}=5.914$, $P=0.052$ ), and those values correspond with shifts in trophic structure (Fig. 6a-c). In the upper mesophotic depths, between 45 and $65 \mathrm{~m}$, sessile invertebrate feeders (Chaetodon capistratus) and roving herbivores (Scarinae) were the most abundant groups (Fig. 6a, b). With increasing depth, Kyphosus sp. and Chromis aff. enchrysura increased in abundance (Fig. 6b, c). Planktivores $(P$. furcifer and Chromis aff. enchrysura) were the most abundant group between 70 and $80 \mathrm{~m}$, followed by mobile invertebrate feeders (Holocentridae) and macro-carnivores (Carangidae and $P$. volitans), whereas sessile invertebrate feeders and roving herbivores were almost absent (Fig. 6c).

In Curaçao, all community values decreased with depth (Fig. 5f-h; richness $H$ test, $X^{2}=14.824, P=0.005$; abundance $H$ test, $X^{2}=12.534, \quad P=0.014$; biomass $H$ test, $X^{2}=10.808, P=0.029$ ). Mobile invertebrate feeders were the most abundant guild in almost all depth strata (Fig. 7a-e). Coryphopterus spp. were most abundant in the upper mesophotic zone $(45-80 \mathrm{~m})$, while A. nikkiae was most abundant in the lower mesophotic zone (85-130 m). Bullisichthys caribbaeus, Corniger spinosus, Decodon puellaris, Halichoeres bathyphilus and Serranus phoebe were mobile invertebrate feeders exclusively found in the lower mesophotic zone (ESM Table S1).

Planktivores were the second most abundant group in all mesophotic depth strata of Curaçao (Fig. 7). Chromis spp. were most abundant in the upper mesophotic zone (Fig. 7a-c), while Pronotogrammus martinicensis was most important in the lower mesophotic zone (Fig. 7d, e). The territorial herbivore $S$. partitus was particularly abundant in the upper mesophotic zone (Fig. 7a) and was replaced by Centropyge argi with increasing depth (Fig. 7b-d). The omnivore Canthigaster rostrata was most abundant in the upper mesophotic zone, while its congener C. jamestyleri was evenly distributed along upper and lower mesophotic zones (ESM Table S1). Prognathodes aculeatus was the only sessile invertebrate feeder recorded in the UVCs in the lower mesophotic zone, and the most abundant macro-carnivores, Cephalopholis cruentata, $P$. volitans and Lutjanus mahogoni, were found in both upper and lower mesophotic zones (ESM Table S1). Roving herbivores occurred only in upper mesophotic depths (Fig. 7a, b; ESM Table S1).

\section{Biogeography}

Samples from the upper mesophotic zones of Bermuda clustered together with $10 \%$ Bray-Curtis similarity among sites (Fig. 8; Table 1), but were isolated from the other locations (Fig. 8). Scarus taeniopterus and Chromis aff. enchrysura made the greatest contribution to within-group Bray-Curtis similarities (34.3 and $23.4 \%$, respectively, in the SIMPER analyses; Table 1). The upper mesophotic zones $(<80 \mathrm{~m})$ of Puerto Rico and Curaçao clustered together (35\% similarity, Table 1), where Chromis insolata and Coryphopterus personatus were the most important contributors to within-group similarities (29.4 and $24 \%$, respectively, in the SIMPER analyses; Table 1). The lower mesophotic zone of Curaçao (85-130 m) had $44 \%$ similarity within sites and was separated from all other upper mesophotic zones, but more closely related to those from Puerto Rico and Curaçao (85\% Bray-Curtis dissimilarity; Table 1) than to Bermuda (93\% Bray-Curtis dissimilarity; Table 1) (Fig. 8). Antilligobius nikkiae and Pronotogrammus martinicensus were identified as the species that contributed most to within-group similarities (34 and $16.3 \%$, respectively, in the SIMPER analyses, 
Fig. 4 Mean abundance and biomass $( \pm \mathrm{SE})$ of reef fish trophic guilds on mesophotic reefs in Bermuda (a, c) and Curaçao (b, d). Different shading within bars represent the various taxonomic groups displayed above the chart
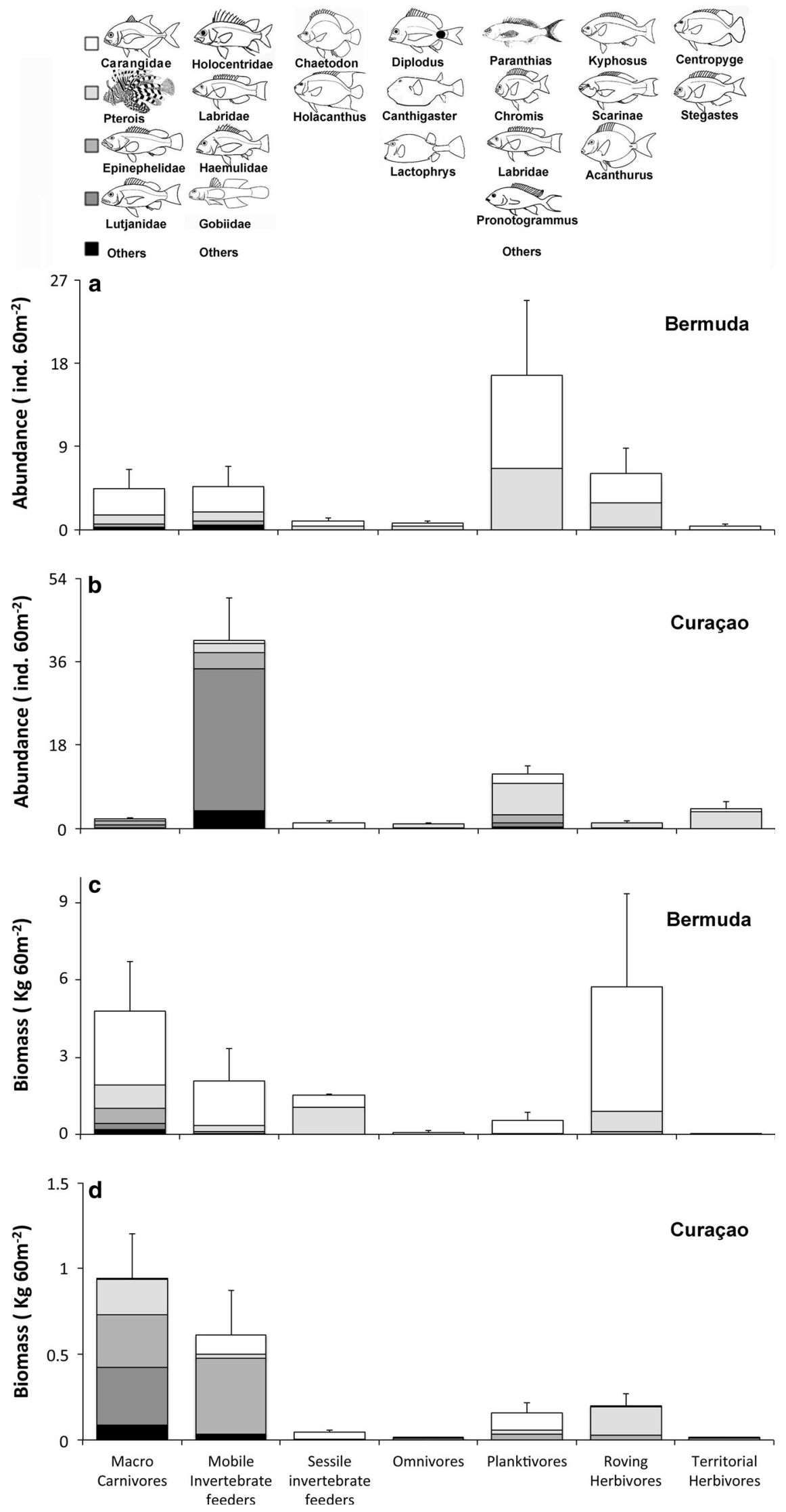

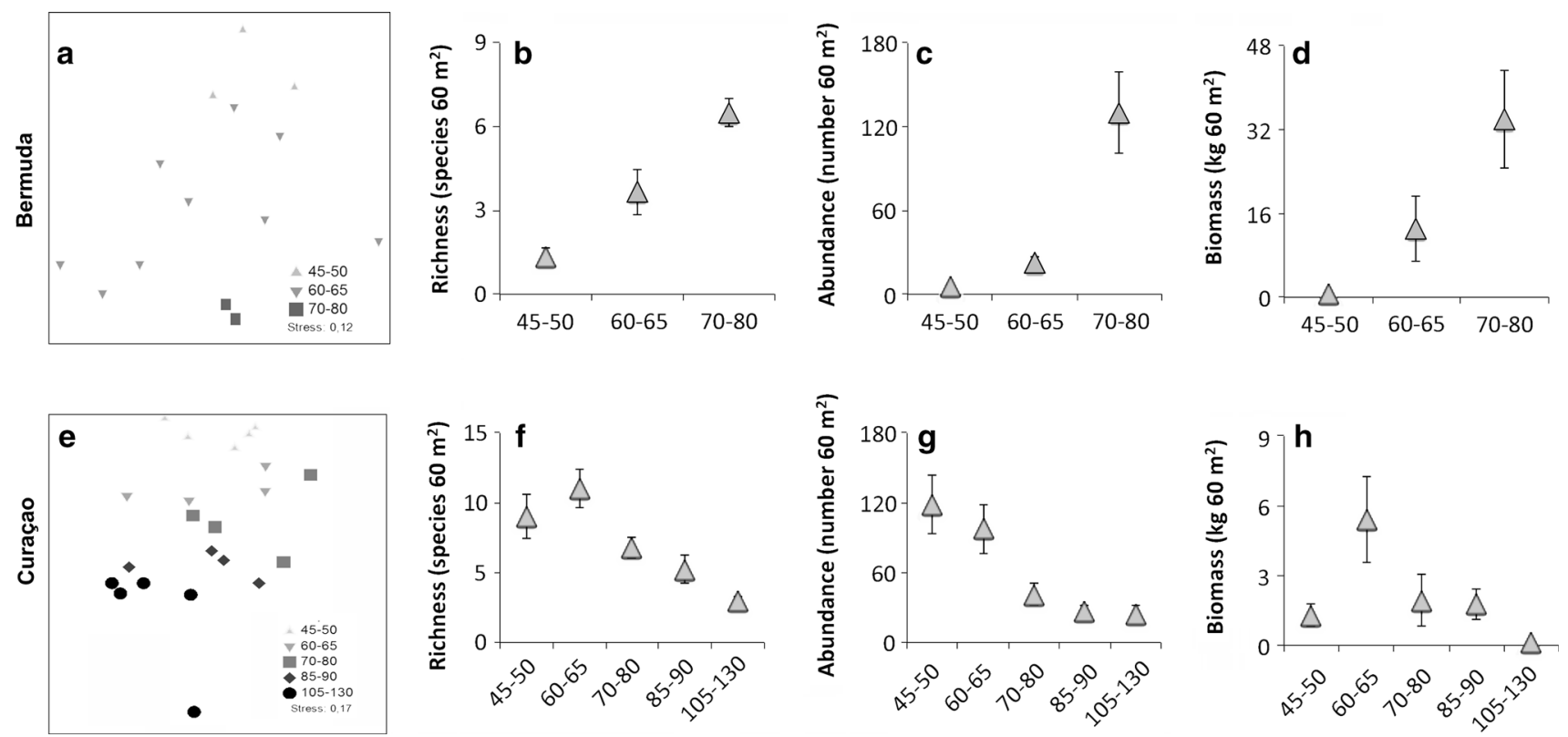

Fig. 5 MDS analysis of Bray-Curtis similarity of reef fish abundance (number $\left.60 \mathrm{~m}^{-2}\right)$ and mean values $( \pm$ SE) of richness, abundance and biomass showing the changes in mesophotic reef fish communities along a depth gradient in Bermuda (a-d) and Curaçao (e-h)

Table 1). Species that contributed to Bray-Curtis dissimilarities between groups are given in Table 1 .

\section{Discussion}

This study represents the first in situ assessment using UVCs for characterizing mesophotic reef fish communities in Bermuda and Curaçao, and the first UVC assessment of lower mesophotic zones (up to $130 \mathrm{~m}$ ) in the Caribbean. The high abundances of small planktivorous fishes (19-50\%) and high relative biomass of macro-carnivores (36-47\%) reported in this study seem a common feature shared with other MCEs, such as of Puerto Rico (Bejarano et al. 2014), Florida (Bryan et al. 2013) and Brazil (Feitoza et al. 2005) in the Atlantic Ocean, and the Marshall Islands in the Pacific (Thresher and Colin 1986). Interestingly, this community structure is similar to that observed in shallow reefs of some oceanic islands of the South Atlantic (Pinheiro et al. 2011; Longo et al. 2015), but different from most Caribbean shallow reefs (Newman et al. 2006). The high abundance of planktivores is related to food availability, sustained by currents and upwelling events (Thresher and Colin 1986), attracting macro-carnivores that presumably feed on planktivores. Conversely, herbivores and corallivores are constrained by the low abundance of their respective food items (Thresher and Colin 1986).

Shallow reefs in Curaçao also supported a high biomass of planktivorous fishes (Sandin et al. 2008a); however, the community structure of shallow and mesophotic reef fishes differs strongly. For instance, mesophotic reefs in Curaçao had smaller overall fish biomass, but higher relative biomass (proportion) of macro-carnivores and mobile invertebrate feeders compared with shallow waters (Sandin et al. 2008a).

Little information is available about reef fish community structure on Bermuda's reefs. Although recent evaluations show a threefold increase in the biomass of herbivorous fishes (Scarinae and Acanthuridae) $6 \mathrm{yr}$ after the fish pot ban introduced in 1990 (Luckhurst 1996; Luckhurst and Farrell 2013), the high biomass of roving herbivores found at mesophotic depths was not expected, since that has not been found in other Caribbean MCEs (Garcia-Sais 2010; Bryan et al. 2013; Bejarano et al. 2014). The clear oceanic water surrounding Bermuda allows deep light penetration and the occurrence of macro-algae below $100 \mathrm{~m}$ (S.R. Smith pers. comm.), and this clarity may facilitate foraging condition by herbivores, thereby supporting their high abundance on upper MCEs in Bermuda.

Pinheiro et al. (2015) found analogous communities with several shallow-water species present on MCEs on South American seamounts. Additionally, many coastal species were previously reported in MCE habitats of the Challenger and Argus seamounts, situated 22 and $37 \mathrm{~km}$ SW of Bermuda, respectively, with summits reaching $\sim 50$ m depth (Smith-Vaniz et al. 1999; Calder 2000). An alternative hypothesis for the presence of shallow-water species on MCEs in Bermuda is the limited availability of shallow habitat on nearby seamounts, which may contribute to species adaptation and plasticity by selecting for individuals able to recruit to mesophotic depths, a process known as "matching habitat choice" (Edelaar et al. 2008). 
Fig. 6 Mean abundance $( \pm S E)$ of reef fish trophic guilds along different mesophotic depth strata in Bermuda: $45-50 \mathrm{~m}$ (a), 60-65 $\mathrm{m}$ (b) and 70-80 m (c). Different shading within bars represent the various taxonomic groups displayed above the chart

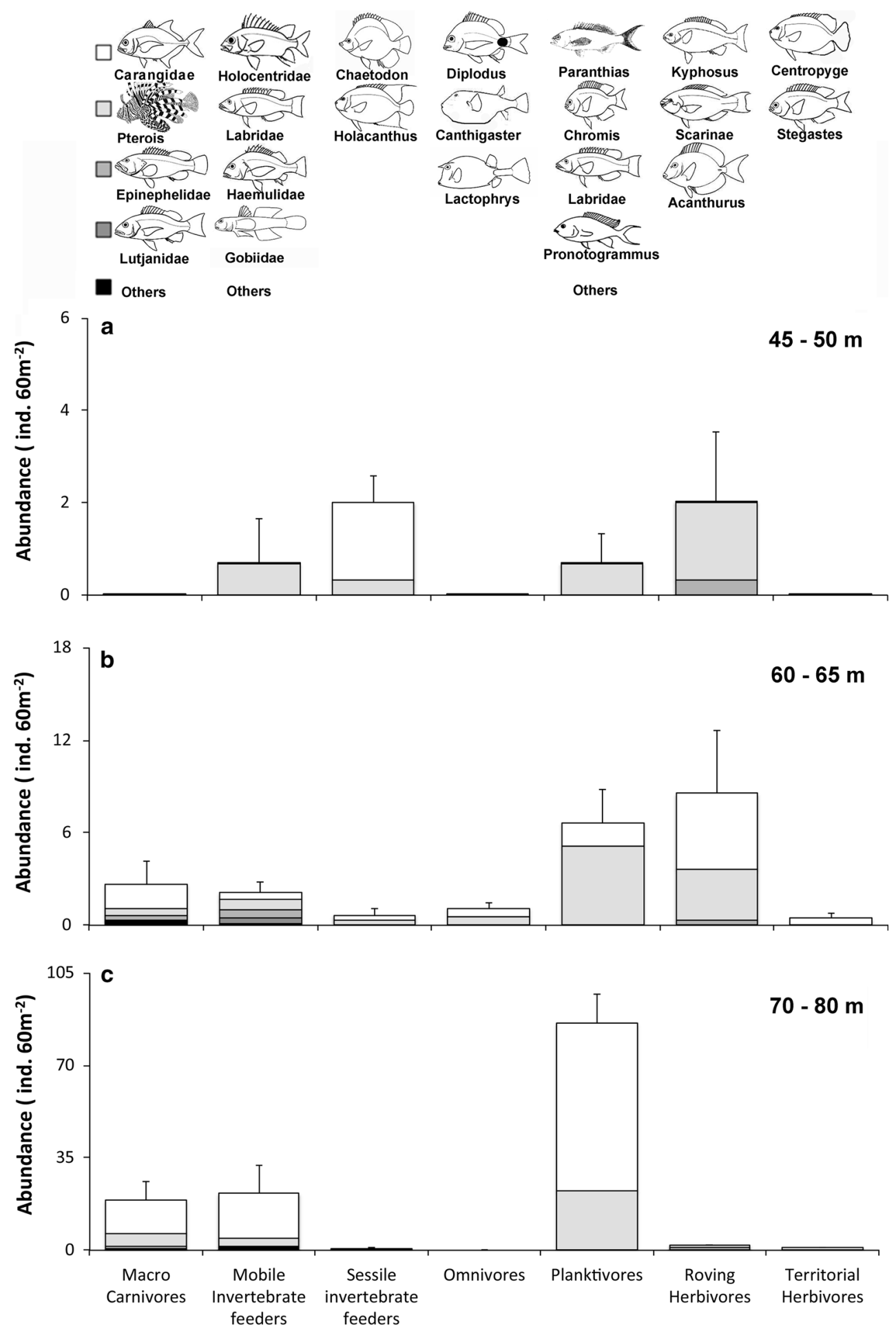

The community structure at both locations strongly changed with depth. Vertical compositional changes in planktivores (Chromis spp. to P. martinicensis) and territorial herbivores (S. partitus to $C$. argi) were also observed. Thresher and Colin (1986) proposed a zonation, where depths of 75-90 m marked a limit to the distribution of many Pacific Ocean shallow-water species, describing replacements of Chromis spp. and Anthiinae species. Colin (1974, 1976) illustrated a similar observation, with the dominance of a few planktivore species below $90 \mathrm{~m}$ in different places in the Caribbean. The results presented here also corroborate this zonation pattern, showing a high turnover in the reef fish community between 70 and $90 \mathrm{~m}$ (Fig. 8). 
Fig. 7 Mean abundance $( \pm \mathrm{SE})$ of reef fish trophic guilds along different mesophotic depth classes in Curaçao: $45-50 \mathrm{~m}$ (a), 60-65 m (b), 70-80 m (c), 85-90 $\mathrm{m}$ (d) and 105-130 m (e). Different shading within bars represent the various taxonomic groups displayed above the chart
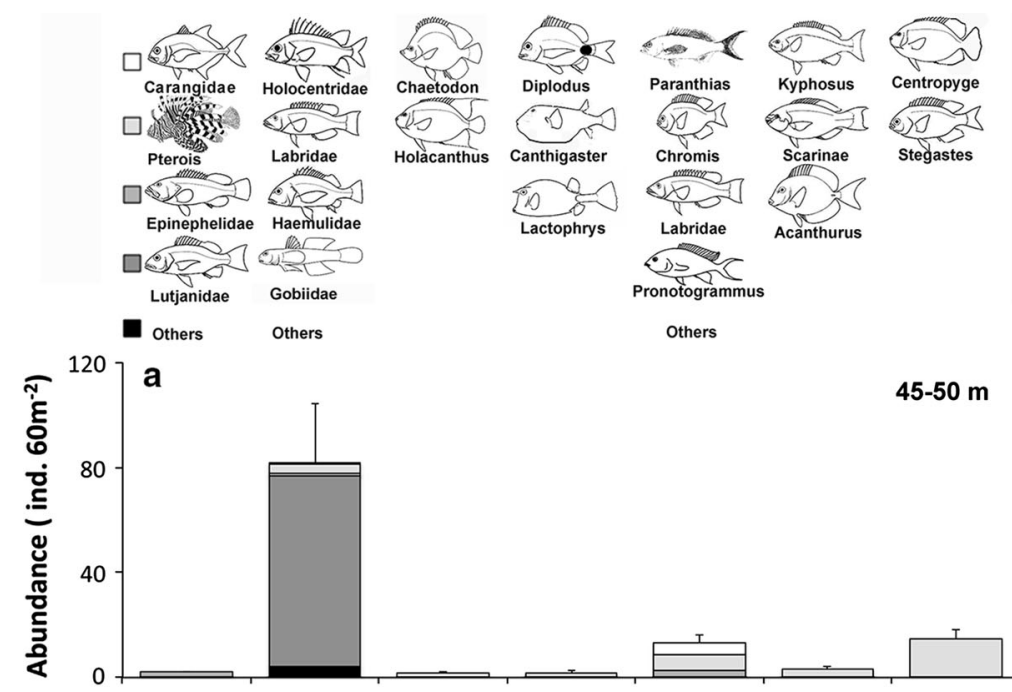

45-50 m
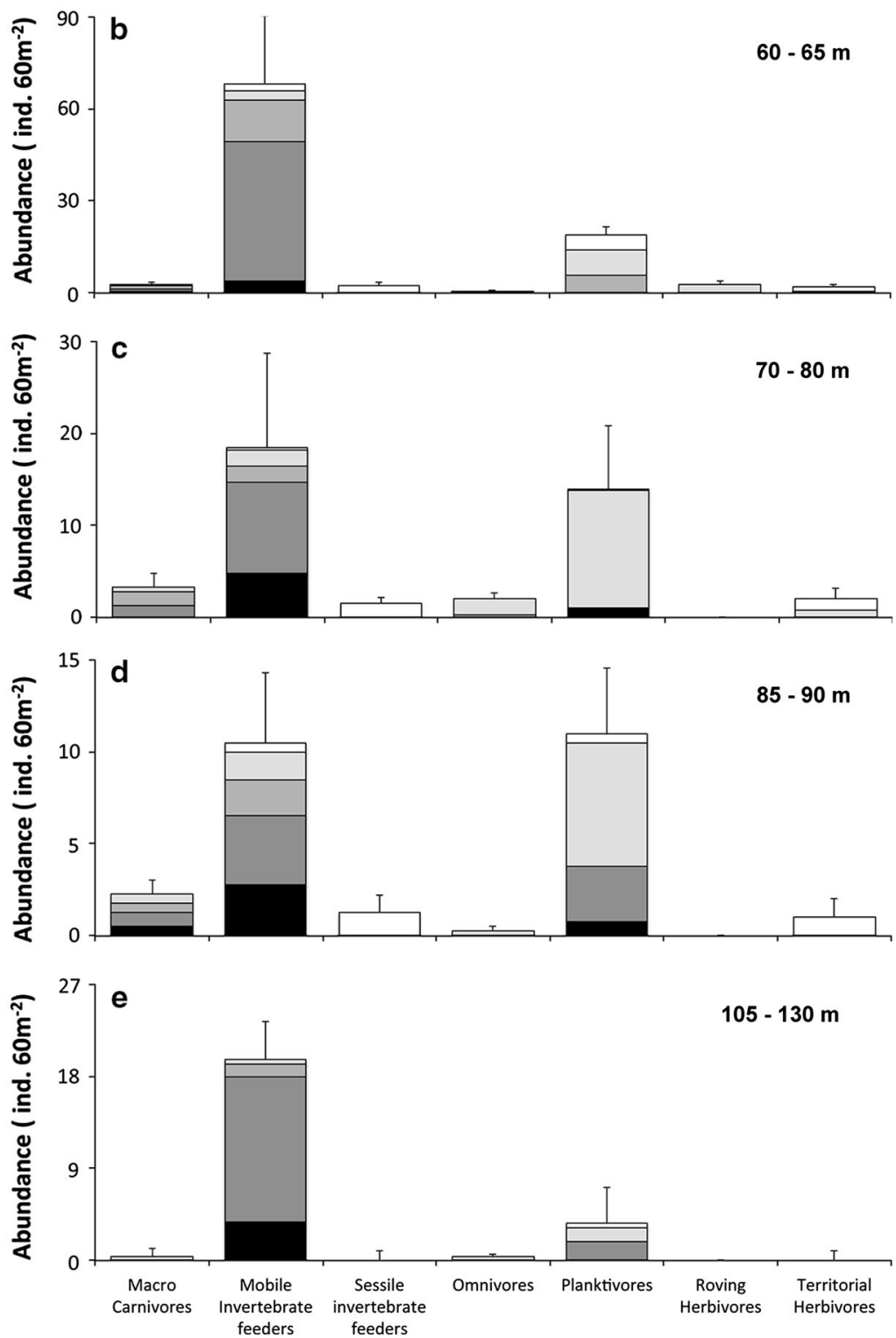


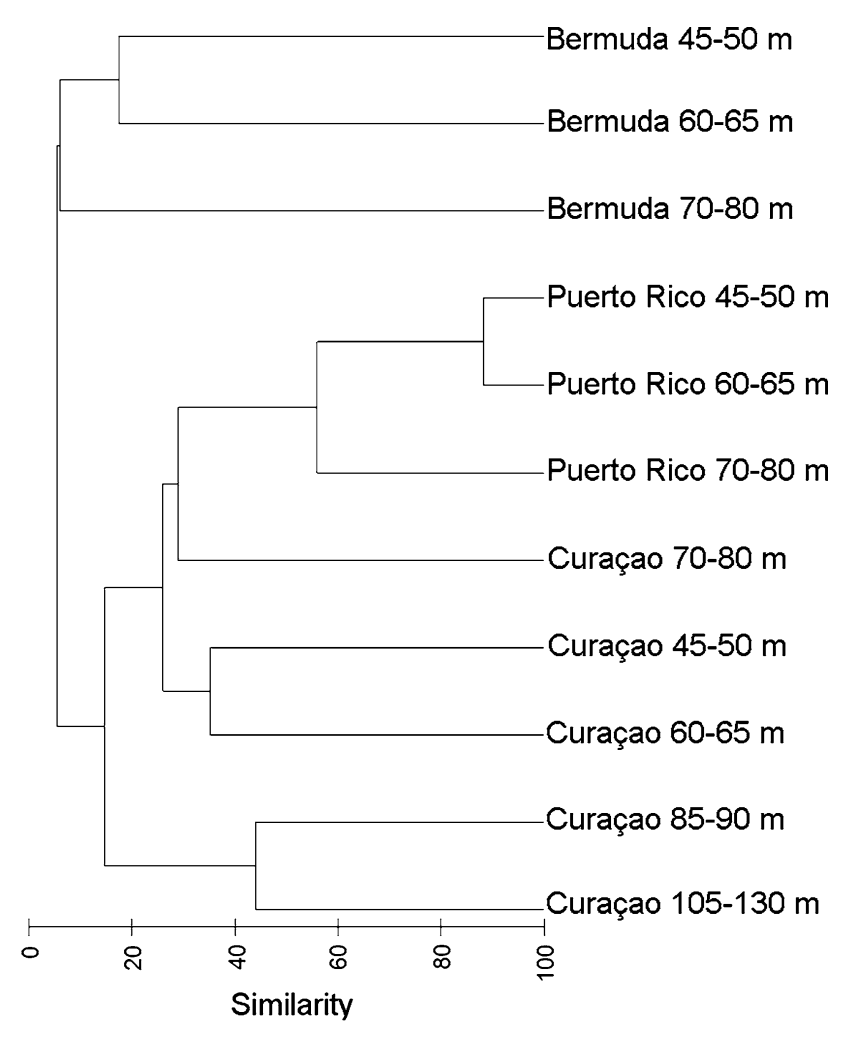

Fig. 8 Cluster analysis showing the Bray-Curtis similarity of reef fish abundance (number $60 \mathrm{~m}^{-2}$ ) among mesophotic depth strata of different Caribbean locations

However, habitat differences may exert an effect as strong as depth (Colin 1974) and may influence vertical and geographic community differences. Curaçao and Puerto Rico (and potentially most Caribbean islands) shelter diverse and well-developed coral reef systems in the upper mesophotic zone $(45-80 \mathrm{~m})$, whereas Bermuda is characterized predominantly by coralline algal reefs at the same depth range. Rhodolith beds, a common feature of MCEs worldwide (Foster 2001; Meirelles et al. 2015), were not found in Curaçao, but were common in Bermuda, and may contribute to the distinctiveness of reef fish communities and inter-site variability in the upper mesophotic zone. Thus, strong disparity between Bermuda and Curaçao mesophotic fish communities may reflect environmental differences, giving rise to biogeographically distinct communities (Robertson and Cramer 2014).

Moreover, effects of distance from the continental shelf and isolation seem to be stronger in Bermuda, since its upper MCE shows a high abundance of locally endemic fishes (Chromis bermudae and Diplodus bermudensis correspond to $9 \%$ of the mesophotic reef fish community). Bermuda has seven endemic fishes in total (Smith-Vaniz and Collette 2013), while Curaçao does not have any (even though Haptoclinus dropi is only known from Curaçao, it is an MCE species likely to be found elsewhere in the
Caribbean; Baldwin and Robertson 2013). Overall, the present dataset suggests that depth is an important driver of variation in the community structure of islands in the Greater Caribbean, but geography also plays a major role in the structure of isolated islands (such as Bermuda). Future work is necessary to disentangle the effects of habitat variability, depth and geography on MCE fish community structure.

In addition to the community contrast, the studied localities showed an opposite pattern of structure along depth gradients. Whereas Curaçao showed the common pattern of a decrease in richness, abundance and biomass with depth (Kahng et al. 2010), Bermuda showed the opposite. Fishing pressure may have influenced this pattern (Luckhurst and Ward 1996). Commercial and recreational fishing activities such as angling, trawling and lobster pots are historically widespread in Bermuda and lead to local overexploitation of shallower reefs (Butler et al. 1993; Smith et al. 2013). In this study, large groupers, snappers, jacks and even a silky shark were sighted during deeper dives at the most distant sites in Bermuda. Furthermore, reproductive aggregations of black groupers and other commercially important fishes have also been recently reported from mesophotic reefs in Bermuda (Luckhurst and Ward 1996; Smith-Vaniz and Collette 2013; authors pers. obs.). The low abundance of top predators in Curaçao is also evidence of the impact of fishing (Vermeij 2012), but since its shelf is very narrow, fishing seems to have a more homogeneous impact through the depth gradient.

Many authors suggest that mesophotic reefs may function as a refuge for targeted commercial species (Feitoza et al. 2005; Bejarano et al. 2014). Curaçao does not show any sharp increase in predator biomass or abundance with depth, and their total biomass is comparable to overexploited Caribbean reefs (Newman et al. 2006). The lower mesophotic zone had a high community turnover, where many shallow-water species and individuals, including commercially targeted species, were recorded (mostly $<90 \mathrm{~m}$; ESM Table S1). Bermuda, on the other hand, showed strong evidence supporting the deep reef refugia hypothesis. The island has seasonal protection for certain commercial species, and subsequent increases in size-frequency distributions were reported following implementation of this legislation (Luckhurst and Trott 2008). However, the biomass of apex predators found in this study was only half that recorded in pristine areas of the Caribbean and Pacific, where macro-carnivore contribution can reach between 30 and $80 \%$ of total fish biomass (Newman et al. 2006; Knowlton and Jackson 2008; Sandin et al. 2008b). In addition, in contrast to other Caribbean mesophotic reefs (Bejarano et al. 2014), the invasive predatory lionfish, Pterois volitans, was present in high abundance and biomass at depth and may be directly impacting both 
Table 1 Species causing intra-group similarities (70\% cumulative) and inter-group dissimilarities (50\% cumulative) based on Bray-Curtis similarity and dissimilarity on MCE localities and depth strata of Great Caribbean

\begin{tabular}{|c|c|c|c|c|c|}
\hline Species & Contrib\% & Cumul.\% & Species & Contrib\% & Cumul. \% \\
\hline \multicolumn{3}{|l|}{ Bermuda group } & \multicolumn{3}{|c|}{ Bermuda versus Curaçao and Puerto Rico upper MCE } \\
\hline \multicolumn{3}{|l|}{ Average similarity $=9.87$} & \multicolumn{3}{|l|}{ Average dissimilarity $=94.99$} \\
\hline Scarus taeniopterus & 34.30 & 34.30 & Coryphopterus personatus & 17.91 & 17.91 \\
\hline Chromis aff. enchrysura & 23.40 & 57.70 & Chromis insolata & 14.52 & 32.43 \\
\hline Chaetodon sedentarius & 8.07 & 65.77 & Paranthias furcifer & 11.09 & 43.52 \\
\hline \multirow[t]{2}{*}{ Paranthias furcifer } & 6.90 & 72.67 & Coryphopterus hyalinus & 6.24 & 49.77 \\
\hline & & & Chromis aff. enchrysura & 4.24 & 54.01 \\
\hline \multicolumn{3}{|c|}{ Curaçao and Puerto Rico upper MCE group } & \multicolumn{3}{|c|}{ Bermuda versus Curaçao lower MCE } \\
\hline \multicolumn{3}{|l|}{ Average similarity $=35.31$} & \multicolumn{3}{|l|}{ Average dissimilarity $=92.87$} \\
\hline Chromis insolata & 29.41 & 29.41 & Antilligobius nikkiae & 19.69 & 19.69 \\
\hline Coryphopterus personatus & 24.01 & 53.42 & Paranthias furcifer & 15.95 & 35.64 \\
\hline Halichoeres garnoti & 8.41 & 61.83 & Chromis aff. enchrysura & 7.84 & 43.48 \\
\hline Coryphopterus spp. & 4.26 & 66.09 & Pronotogrammus martinicensis & 5.14 & 48.62 \\
\hline Cephalopholis cruentata & 3.61 & 69.70 & Holocentrus ascensionis & 4.09 & 52.71 \\
\hline Chromis cyanea & 2.60 & 72.30 & & & \\
\hline \multicolumn{3}{|l|}{ Curaçao lower MCE group } & \multicolumn{3}{|c|}{ Curaçao and Puerto Rico upper MCE versus Curaçao lower MCE } \\
\hline \multicolumn{3}{|l|}{ Average similarity $=43.98$} & \multicolumn{3}{|l|}{ Average dissimilarity $=85.34$} \\
\hline Antilligobius nikkiae & 33.94 & 33.94 & Coryphopterus personatus & 21.69 & 21.69 \\
\hline Pronotogrammus martinicensis & 16.29 & 50.23 & Chromis insolata & 15.74 & 37.43 \\
\hline Chromis aff. enchrysura & 12.67 & 62.90 & Antilligobius nikkiae & 11.27 & 48.70 \\
\hline Bullisichthys caribbaeus & 11.31 & 74.21 & Coryphopterus hyalinus & 7.57 & 56.27 \\
\hline
\end{tabular}

Species are ordered in decreasing percent contribution (Contrib\%)

studied locations in the same way as it has strongly impacted Bahamian MCEs (Lesser and Slattery 2011).

As the impacts of biotic and abiotic stressors increase on shallow reef systems, a clear understanding of MCEs will become essential for effective management and conservation. Whether MCEs serve as a refuge or are already overexploited can only be determined through extensive surveying and assessment of community structure and reef health. Healthy reef ecosystems are more resistant to major natural disturbances (Bruce et al. 2012), and the best option for conservation and management has been the creation and enlargement of marine-protected areas (Clark and Dunn 2012; Sheppard et al. 2012) that support high diversity and biomass of reef fish species (Newman et al. 2006). Given the degree of biodiversity found at MCEs in the two Caribbean locations in this study, raising awareness and promoting the conservation of deep reefs seem critical for biodiversity maintenance and sustainable fisheries in the Greater Caribbean.

Acknowledgments Funding for this study was provided by the California Academy of Sciences, DarwinPlus Award (DPLUS001) from the UK Department of Environment, Food, and Rural Affairs, and the Ocean Support Foundation. We are also thankful to Hollis, the Bermuda Institute of Ocean Sciences, the dive team at Triangle
Diving, Dutch and the Substation Curaçao crew for their support in completing this work. Specifically, we thank G. Maddocks, F. Williams Jr., S. Bennett and M. Cooper for boating and gas mixing assistance, and J. P. Quimbayo, W. Love and M. Lane for technical support. We also thank S. R. Smith and three anonymous reviewers for the helpful comments that greatly improved this manuscript. H.T.P. is recipient of a doctoral fellowship from CNPq (Ciência sem Fronteiras; GDE 202475/2011-5). This manuscript is BIOS contribution \#2039.

Open Access This article is distributed under the terms of the Creative Commons Attribution 4.0 International License (http://crea tivecommons.org/licenses/by/4.0/), which permits unrestricted use, distribution, and reproduction in any medium, provided you give appropriate credit to the original author(s) and the source, provide a link to the Creative Commons license, and indicate if changes were made.

\section{References}

Bak RPM, Nieuwland G, Meesters EH (2005) Coral reef crisis in deep and shallow reefs: 30 years of constancy and change in reefs of Curaçao and Bonaire. Coral Reefs 24:475-479

Baldwin CC, Robertson DR (2013) A new Haptoclinus blenny (Teleostei, Labrisomidae) from deep reefs off Curaçao, southern Caribbean, with comments on relationships of the genus. ZooKeys 81:71-81

Baldwin CC, Johnson GD (2014) Connectivity across the Caribbean Sea: DNA barcoding and morphology unite an enigmatic fish 
larva from the Florida straits with a new species of sea bass from deep reefs off Curaçao. PLoS One 9:e97661

Bejarano I, Appeldoorn RS, Nemeth M (2014) Fishes associated with mesophotic coral ecosystems in La Parguera, Puerto Rico. Coral Reefs 33:313-328

Bongaerts P, Ridgway T, Sampayo EM, Hoegh-Guldberg O (2010) Assessing the "deep reef refugia" hypothesis: focus on Caribbean reefs. Coral Reefs 29:309-327

Bruce T, Meirelles PM, Garcia G, Paranhos R, Rezende CE, Moura RL, Francini-Filho R, Coni EOC, Vasconcelos AT, AmadoFilho G, Hatay M, Schmieder R, Edwards R, Dinsdale E, Thompson FL (2012) Abrolhos Bank reef health evaluated by means of water quality, microbial diversity, benthic cover, and fish biomass data. PLoS One 7:e36687

Bryan DR, Kilfoyle K, Gilmore RG, Spieler RE (2013) Characterization of the mesophotic reef fish community in south Florida, USA. J Appl Ichthyol 29:108-117

Butler JN, Burnett-Herkes J, Barnes JA, Ward J (1993) The Bermuda fisheries. A tragedy of the commons averted? Environment 35:6-33

Calder DR (2000) Assemblages of hydroids (Cnidaria) from three seamounts near Bermuda in the western North Atlantic. Deep Sea Res Part 1 Oceanogr Res Pap 47:1125-1139

Clark MR, Dunn MR (2012) Spatial management of deep-sea seamount fisheries: balancing sustainable exploitation and habitat conservation. Environ Conserv 39:204-214

Coates K, Fourqurean J, Kenworthy W, Logan A, Manuel S, Smith S (2013) Introduction to Bermuda: geology, oceanography and climate. In: Sheppard C (ed) Coral reefs of the world. Coral reefs of the UK overseas territories. Springer, pp 115-133

Colin PL (1974) Observation and collection of deep-reef fishes off the coasts of Jamaica and British Honduras (Belize). Mar Biol 24:29-38

Colin PL (1976) Observations of deep-reef fishes in the Tongue-ofthe-ocean, Bahamas. Bull Mar Sci 26:603-605

Dennis G, Bright T (1988) Reef fish assemblages on hard banks in the northwestern Gulf of Mexico. Bull Mar Sci 43:280-307

Edelaar P, Siepielski AM, Clobert J (2008) Matching habitat choice causes directed gene flow: a neglected dimension in evolution and ecology. Evolution 62:2462-2472

Feitoza BM, Rosa RS, Rocha LA (2005) Ecology and zoogeography of deep-reef fishes in northeastern Brazil. Bull Mar Sci 76:725-742

Ferreira C, Floeter S, Gasparini JL, Ferreira BP, Joyeux J (2004) Trophic structure patterns of Brazilian reef fishes: a latitudinal comparison. J Biogeogr 31:1093-1106

Foster M (2001) Rhodoliths: between rocks and soft places. J Phycol 37:659-667

Froese R, Pauly D (2014) Fishbase. www.fishbase.org, version (08/ 2014)

Garcia-Sais JR (2010) Reef habitats and associated sessile-benthic and fish assemblages across a euphotic-mesophotic depth gradient in Isla Desecheo, Puerto Rico. Coral Reefs 29: 277-288

Hixon MA (2011) 60 years of coral reef fish ecology: past, present, future. Bull Mar Sci 87:727-765

Jackson JBC, Donovan MK, Cramer KL, Lam VV (editors). (2014) Status and trends of Caribbean coral reefs:1970-2012. Global Coral Reef Monitoring Network, IUCN, Gland, Switzerland

Kahng SE, Garcia-Sais JR, Spalding HL, Brokovich E, Wagner D, Weil E, Hinderstein L, Toonen RJ (2010) Community ecology of mesophotic coral reef ecosystems. Coral Reefs 29:255-275

Knowlton N, Jackson JBC (2008) Shifting baselines, local impacts, and global change on coral reefs. PLoS Biol 6:e54

Lesser MP, Slattery M (2011) Phase shift to algal dominated communities at mesophotic depths associated with lionfish
(Pterois volitans) invasion on a Bahamian coral reef. Biol Invasions 13:1855-1868

Liddell WD, Ohlhorst SL (1988) Hard substrata community patterns, North Jamaica. Palaios 3:413-423

Locke J, Bilewitch J, Coates K (2013a) Scleractinia, Octocorallia and Antipatharia of Bermuda's reefs and deep-water coral communities: a taxonomic perspective including new records. In: Sheppard C (ed.) Coral reefs of the world. Coral reefs of the UK overseas territories. Springer, pp 189-200

Locke J, Coates K, Bilewitch J, Holland L, Pitt J, Smith S, TrapidoRosenthal H (2013b) Biogeography, biodiversity and connectivity of Bermuda's coral reefs. In: Sheppard C (ed.) Coral reefs of the world. Coral reefs of the UK overseas territories. Springer, pp $153-172$

Longo GO, Morais RA, Martins CDL, Mendes TC, Aued AW, Cândido DV, de Oliveira JC, Nunes LT, Fontoura L, Sissini MN, Teschima MM, Silva MB, Ramlov F, Gouvea LP, Ferreira CEL, Segal B, Horta PA, Floeter SR (2015) Between-habitat variation of benthic cover, reef fish assemblage and feeding pressure on the benthos at the only atoll in South Atlantic: Rocas Atoll, NE Brazil. PLoS One 10:e127176

Luckhurst BE (1996) A fishery-independent assessment of Bermuda's coral reef fish stocks by diver census following the fish pot ban - a progress report. Proc Gulf Caribb Fish Inst 46:309-323

Luckhurst B, Ward J (1996) Analysis of trends in Bermuda's fishery statistical database from 1975 to 1990 with reference to fishery management measures implemented during this period. Proc Gulf Caribb Fish Inst 44:306-324

Luckhurst BE, Trott TM (2008) Seasonally closed spawning aggregation sites for red hind (Epinephelus guttatus): Bermuda's experience over 30 years (1974-2003). Proc Gulf Caribb Fish Inst 66:331-336

Luckhurst BE, Farrell SO (2013) Rapid recovery of parrotfish (Scaridae) and surgeonfish (Acanthuridae) populations following the fish pot ban in Bermuda. Proc Gulf Caribb Fish Inst 66:301-306

Lukens RR (1981) Observations of deep-reef ichthyofauna from the Bahama and Cayman Islands, with notes on relative abundance and depth distribution. Gulf Res Reports 71:79-81

Meirelles PM, Amado-Filho GM, Pereira-Filho GH, Pinheiro HT, de Moura RL, Joyeux J-C, Mazzei EF, Bastos AC, Edwards RA, Dinsdale E, Paranhos R, Santos EO, Iida T, Gotoh K, Nakamura S, Sawabe T, Rezende CE, Gadelha LMR, Francini-Filho RB, Thompson C, Thompson FL (2015) Baseline assessment of mesophotic reefs of the Vitória-Trindade Seamount Chain based on water quality, microbial diversity, benthic cover and fish biomass data. PLoS One 10:e0130084

Newman MJH, Paredes GA, Sala E, Jackson JBC (2006) Structure of Caribbean coral reef communities across a large gradient of fish biomass. Ecol Lett 9:1216-1227

Pinheiro HT, Martins AS, Joyeux J-C (2013) The importance of small-scale environment factors to community structure patterns of tropical rocky reef fish. J Mar Biol Assoc U.K. 93:1175-1185

Pinheiro HT, Ferreira CEL, Joyeux J-C, Santos RG, Horta PA (2011) Reef fish structure and distribution in a south-western Atlantic Ocean tropical island. J Fish Biol 79:1984-2006

Pinheiro HT, Mazzei E, Moura RL, Amado-Filho GM, CarvalhoFilho A, Braga AC, Costa PAS, Ferreira BP, Ferreira CEL, Floeter SR, Francini-Filho RB, Gasparini JL, Macieira RM, Martins AS, Olavo G, Pimentel CR, Rocha LA, Sazima I, Simon T, Teixeira JB, Xavier LB, Joyeux J-C (2015) Fish biodiversity of the Vitória-Trindade seamount chain, southwestern Atlantic: an updated database. PLoS One 10:e0118180

Robertson DR, Cramer KL (2014) Defining and dividing the Greater Caribbean: insights from the biogeography of shorefishes. PLoS One 9:e102918 
Sandin S, Sampayo E, Vermeij M (2008a) Coral reef fish and benthic community structure of Bonaire and Curaçao, Netherlands Antilles. Caribb J Sci 44:137-144

Sandin SA, Smith JE, Demartini EE, Dinsdale EA, Donner SD, Friedlander AM, Konotchick T, Malay M, Maragos JE, Obura D, Pantos O, Paulay G, Richie M, Rohwer F, Schroeder RE, Walsh S, Jackson JBC, Knowlton N, Sala E (2008b) Baselines and degradation of coral reefs in the Northern Line Islands. PLoS One 3:e1548

Sheppard CRC, Ateweberhan M, Bowen BW, Carr P, Chen CA, Clubbe C, Craig MT, Ebinghaus R, Eble J, Fitzsimmons N, Gaither MR, Gan C-H, Gollock M, Guzman N, Graham NAJ, Harris A, Jones R, Keshavmurthy S, Koldewey H, Lundin CG, Mortimer JA, Obura D, Pfeiffer M, Price ARG, Purkis S, Raines P, Readman JW, Riegl B, Rogers A, Schleyer M, Seaward MRD, Sheppard ALS, Tamelander J, Turner JR, Visram S, Vogler C, Vogt S, Wolschke H, Yang JM-C, Yang S-Y, Yesson C (2012) Reefs and islands of the Chagos Archipelago, Indian Ocean: why it is the world's largest no-take marine protected area. Aquat Conserv 22:232-261
Smith S, Sarkis S, Murdoch T, Weil E, Croquer A, Bates N, Johnson R, de Putron S, Andersson A (2013) Threats to coral reefs of Bermuda. In: Sheppard C (ed.) Coral reefs of the world. Coral reefs of the UK overseas territories. Springer, pp 173-188

Smith-Vaniz WF, Collette BB (2013) Fishes of Bermuda. Aqua 19:165-186

Smith-Vaniz WF, Collette BB, Luckhurst B (1999) Fishes of Bermuda: history, zoogeography, annotated checklist, and identification keys. Allen Press Inc., Lawrence, KS

Sparks JS, Gruber DF (2012) A new mesophotic clingfish (Teleostei: Gobiesocidae) from the Bahamas. Copeia 2012:251-256

Thresher RE, Colin PL (1986) Trophic structure, diversity and abundance of fishes of the deep reef (30-300 m) at Enewetak, Marshall Islands. Bull Mar Sci 38:253-272

Vermeij M (2012) The current state of Curaçao coral reefs. Carmabi Foundation, Willemstad

Zar J (2010) Biostatistical analysis. Prentice Hall Inc, New Jersey 